\title{
KENAKALAN REMAJA DI SMP KRISTEN BOMBANON
}

\author{
Periance Saliani \\ SMP Kristen Bombanon
}

\begin{abstract}
ABSTRAK
Penelitian ini menuliskan tentang penyebab-penyebab dari kenakalan remaja. Tujuan dari penelitian untuk mengurangi tingkat kenakalan remaja serta dapat merumuskan rekomendasi yang tepat. Jenis penelitian ini merupakan penelitian deskriptif kualitatif. Penelitian ini berjenis penelitian studi kasus dengan subjek tunggal. Studi kasus adalah suatu studi yang mendalam tentang individu dan berjangka waktu relatif lama, terus menerus, artinya kasus dialami oleh satu orang. Subjek penelitian ini adalah remaja yang memenuhi kriteria kenakalan remaja. Jumlah subjek dalam penelitian ini adalah 1 orang, alasan hanya menggunakan 1 orang subjek, yaitu agar dapat melakukan penelitian secara mendalam serta fokus penelitian tidak terbagi oleh subjek lain. Metode penelitian yang diutamakan dalam penelitian ini adalah metode wawancara, observasi. Hasil penelitian ini menghasilkan beberapa penyebab dari kenakalan remaja yaitu kondisi keluarga yang berantakan membuat subjek menjadi remaja yang kurang diperhatikan oleh orang tuanya, status sosio ekonomi keluarga menjadi peyebab kenakalan subjek, pengaruh teman bermain juga berpengaruh terhadap kenakalan remaja, sering keluar rumah pada malam hari, serta pola pemikiran subjek pada saat dan setelah melakukan kenakalan remaja adalah kepuasan dan kebanggaan baginya.
\end{abstract}

Kata Kunci: konsentrasi belajar, bimbingan klasikal, project based learning

\section{PENDAHULUAN}

Kenakalan remaja merupakan salah satu fenomena sosial yang sering ditemui di kalangan siswa atau pelajar. Fenomena ini pun dapat ditemui di berbagai negara termasuk Indonesia. Biasanya kenakalan remaja berkaitan dengan sikap atau tindakan menyimpang yang dilakukan oleh anak-anak usia remaja. Baik dilakukan di lingkungan rumah, sekolah, maupun masyarakat yang lebih luas.

Kenakalan remaja ini pun mempunyai bentuk yang bermacam-macam. Misalnya seperti tindakan membolos sekolah, sengaja mengambil uang atau barang milik orang lain tanpa izin, terlibat dalam geng sekolah yang bentrok dengan sekolah lain, merundung teman di sekolah, atau juga membohongi orang tua untuk hal yang melanggar norma. Selain itu, kenakalan bersifat parah juga dapat berupa tindakan merokok, konsumsi minuman keras, seks bebas hingga penyalahgunaan narkoba yang dilakukan oleh remaja.

Beberapa tindakan kenakalan remaja yang sering terjadi di masyarakat tersebut, menunjukkan bahwa remaja merupakan usia yang perlu diperhatikan. Sebab, di usia remaja adalah masa peralihan di mana anak beranjak menuju dewasa. Tentu pada masa ini akan muncul berbagai perubahan yang mengharuskan setiap anak beradaptasi dengan baik. Sehingga anakanak perlu mendapatkan pendampingan dan pengawasan yang baik oleh orang tua, guru, juga masyarakat.

Dako (2012) Kenakalan remaja dapat dikategorikan sebagai bentuk perilaku menyimpang karena tidak sesuai dengan norma yang ada dimasyarakat dan perbuatan tersebut juga dapat merugikan orang lain serta melanggar hukum yang berlaku. Orangtua sebagai pendidik pertama dan yang utama hendaknya memiliki 
wawasan dan pengetahuan yang luas dalam memberikan bimbingan pada anak remaja. menurut Sarwono ( $2013: 62$ ) Orangtua juga harus mengetahui tentang masa remaja, yaitu masa remaja merupakan masa peralihan dari anak-anak ke dewasa meliputi kondisi psikologis dan kondisi fisik individu. Orangtua yang tidak memiliki pengetahuan tentang masa remaja anaknya dikhawatirkan tidak bisa mendidik dan memberikan pendampingan dengan tepat sehingga remaja akan terjerumus dalam perbuatan yang menyimpang. Perilaku yang menyimpang atau kenakalan remaja adalah suatu perilaku yang global, mulai dari perilaku yang tidak dapat ditoleransi secara sosial seperti kenakalan yang terjadi berkaitan dengan napza, pelanggaran sosial, hingga tindakan kriminal yang merugikan orang lain. Peran keluarga sebagai lingkungan sosial terdekat sangat diperlukan agar anak dapat menjadi pribadi yang peka akan keadaan di lingkungan sekitarnya (Surbakti, 2013)

Kenakalan remaja dapat terjadi karena banyak faktor seperti pergaulannya dengan teman sebaya dan pengaruh dari lingkungan tempatnya berinteraksi setiap harinya serta pengaruh dari dalam dirinya sendiri. Pada masa ini remaja mengalami perubahan pada pertumbuhan dan perkembangannya. Pertumbuhan dan perkembangan yang dimaksud adalah fisik, sosial, emosi, dan psikologisnya. Remaja yang sedang mengalami masa pertumbuhan ini sangat rentan juga melakukan perilaku menyimpang yang ditandai dengan melakukan perbuatan- perbuatan yang melanggar norma dimasyarakat dan hal tersebut dapat menimbulkan keresahan bahkan kerugian bagi orang-orang disekitarnya. Motif kenakalan remaja yang dilakukan bersifat sederhana seperti untuk memenuhi keinginan dan kebutuhan yang sekarang dan bersifat harus segera terlaksana yang bertujuan untuk menghindari kejadian yang tidak mereka sukai dengan melampiaskannya pada suatu bentuk kenakalan yang remaja lakukan. (Aviyah dan Farid, 2014)

Pada masa remaja kepribadian seorang anak dibentuk karena anak akan berproses untuk menemukan jati dirinya. Cara yang dilakukan dalam mencari jati diri juga beragam baik dengan cara yang positif maupun negatif. Pergaulan dan pengaruh lingkungan sekitar menjadi salah satu faktor terbentuknya kepribadian remaja.Perbuatan yang secara nyata dilakukan oleh remaja dan bersifat melanggar hukum serta berlawanan dengan keadaan sosial yang seharusnya, sehingga kondisi tersebut merupakan problem sosial. Problema atau permasalahan sosial menyangkut nilai-nilai sosial dan moral, serta menyangkut tingkah laku yang menyimpang, berlawanan dengan hukum dan bersifat merusak. Maka permasalahan sosial tidak akan dapat diselesaikan tanpa adanya dukungan dari masyarakat, untuk menilai hal apa yang dianggap baik dan yang dianggap buruk.

Masa remaja merupakan masa peralihan dan pertumbuhan yang ditandai dengan perubahan fisik, emosi dan psikis. Ada dua hal yang berpengaruh terhadap kepribadian remaja yaitu pengaruh eksternal dan internal. Pengaruh eksternal yaitu pengaruh lingkungan yang berdampak pada pembentukan kepribadian remaja bahwa lingkungan dimana ia bersosialisasi juga bisa membentuk sifat dan karakter remaja kemudian pengaruh internal adalah pengaruh yang berasal dari dalam diri remaja itu sendiri. Remaja yang bersikap agresif dan arogan akan tumbuh dan berkembang dengan sangat berbeda dari pertumbuhan dan perkembangan yang seharusnya (Sumara, Humaedi, dan Santoso, 2017)

\section{METODE}

Metode penelitian ini menggunakan pendekatan kualitatif deskriptif karena Penelitian kualitatif menurut Bogdan dan 
Taylor, adalah sebagai prosedur sebagai penelitian yang menghasilkan data

deskriptif berupa kata-kata tertulis atau lisan dari orang-orang atau perilaku yang dapat diamati. Peneliti mengadakan penelitian tidak dimaksudkan menjadi hipotesis tertentu tetapi hanya menggambarkan "apa adanya" tentang suatu variable, gejala dan juga keadaan.

Margono menambahkan bahwa dalam penelitian kualitatif ini analisis yang digunakan lebih bersifat deskriptif-analitik yang berarti interpretasi terhadap isi dibuat dan disusun secara sistematik/menyeluruh dan sistematis. Selain itu penggunaan metode penelitian kualitatif juga mengarahkan pusat perhatian kepada cara bagaimana orang memberi makna pada kehidupannya dalam pengertian lain peneliti menekankan pada titik pandang orang-orang atau yang disebut "people's point of view", dan pemaparan hasil penelitian berdasarkan data dan informasi lapangan dengan menarik makna dan konsepnya. Berdasarkan pendapat-pendapat di atas, maka jenis penelitian evaluasi dengan pendekatan kualitatif sesuai dengan tujuan dari penelitian ini yaitu untuk mengetahui Penyebab Kenakalan Remaja di SMP Kristen Bombanon.

\section{HASIL DAN PEMBAHASAN}

SMP Kristen Bombanon merupakan salah satu Sekolah Menengah Pertama yang ada di Kecamatan Mantoh Kabupaten Banggai Provinsi Sulawesi Tengah, lebih tepatnya di desa Bombanon. SMP Kristen Bombanon ini terletak di Jalan Yohanis No. 02, Desa Bombanon. Dengan letak yang geografis berada di depan dijalan raya memudahkan sekolah ini untuk dijangkau. SMP Kristen Bombanon ini dapat dijangkau oleh peserta didik hanya dengan dengan kendaraan pribadi maupun jalan kaki mengingat sekolah ini berada tidak jauh dari perkampungan. Berdasarkan pengamatan yang dilakukan oleh peneliti, peserta didik
SMP Kristen Bombanon berangkat sekolah dengan mengendarai sepeda, jalan kaki, dan ada juga yang membawa kendaraan bermotor sendiri.

Cara mengetahui apa yang menjadi alasan remaja melakukan aktivitas di luar rumah pada malam hari adalah dengan membuat angket atau kuesioner untuk beberapa orang sebagai sampel. Dilihat dari segi alasan, remaja melakukan kebiasaan itu karena pengaruh dari teman dan kurangnya perhatian orang tua. Mereka melakukan berbagai cara untuk keluar rumah, beberapa keluar secara diam-diam karena tidak diberi izin oleh orang tuanya, ada pula orang tua yang terpaksa memberi izin karena anak yang terus memaksa untuk keluar rumah, dan ada pula orang tua yang secara sukarela memberi izin anaknya untuk keluar malam. Waktu yang digunakan untuk keluar rumah bervariasi, biasanya mulai pukul 19.00 23.00 WITA. Hal yang biasa mereka lakukan ialah sekedar berkumpul dengan teman, mengerjakan tugas, maupun pacaran.

Pada umumnya, malam merupakan waktu untuk beristirahat di rumah. Namun, tidak semua orang khususnya remaja merasa senang berada di dalam rumah pada malam hari. Ketika mereka merasa malas atau tidak senang berada di rumah, mereka cenderung akan keluar rumah dan melakukan hal yang mereka senangi. Tidak diragukan bahwa keluarga memegang peranan penting dalam pembentukan pribadi remaja. Karena itu, baik buruknya struktur keluarga memberikan pengaruh baik atau buruk kepribadian seorang anak. Keluarga yang tidak harmonis akan menyebabkan anak kurang mendapatkan perhatian dan kasih sayang orang tua akan cenderung mudah terpengaruh oleh lingkungan sekitar. Namun, memberi perhatian yang lebih juga akan berdampak buruk bagi anak. Anak 
akan merasa dikekang dan frustasi. Hal itu menyebabkan anak merasa tidak nyaman.

Sekolah merupakan tempat dimana anak mendapatkan pendidikan selain dari orang tuanya. Sekolah mengajarkan anak untuk berperilaku baik dan santun. Oleh karena itu, sekolah memiliki peranan penting untuk pengembangan kepribadian anak selain dari keluarga. Hasil angket yang saya lakukan menunjukkan bahwa faktor yang paling besar yang menyebabkan terjadinya kenakalan remaja adalah teman. Tidak dapat dipungkiri lagi, banyak kasus kenakalan remaja terjadi karena pengaruh dari teman. Pergaulan dengan teman sebaya yang sering mempengaruhi untuk melakukan suatu hal baru malah dapat menjerumuskan ke kenakalan remaja.

Kenakalan remaja saat ini berdampak pada remaja itu sendiri dan lingkungan sekitar. Berikut dampak yang ditimbulkan dari kenakalan remaja. Dampak kenakalan remaja pasti akan berimbas pada remaja tersebut. Bila tidak segera ditangani, ia akan tumbuh menjadi sosok yang berkepribadian buruk. Remaja yang melakukan kenakalan tertentu pasti akan dihindari atau malah dikucilkan oleh banyak orang. Remaja tersebut akan dianggap sebagai pengganggu dan orang yang tidak berguna. Akibat dari dikucilkannya ia dari pergaulan sekitar, remaja tersebut dapat mengalami gangguan kejiwaan. Gangguan kejiwaan bukan berarti gila, tapi ia akan merasa terkucilkan dalam hal sosialisasi, merasa sedih, atau malah akan membenci orang-orang di sekitarnya.

Masa depan yang suram dan tidak menentu. Bayangkan bila ada seorang remaja yang kemudian terpengaruh pergaulan bebas, hampir bisa dipastikan dia tidak akan memiliki masa depan cerah. Hidupnya akan hancur perlahan dan tidak sempat memperbaikinya. Remaja yang terjebak hal-hal negatif bukan tidak mungkin memiliki keberanian untuk melakukan tindak kriminal.
Upaya yang dapat dilakukan untuk mengatasi kebiasaan keluar malam adalah harus ada kemauan dari orang tua untuk menciptakan keadaan harmonis dan nyaman. Lingkungan masyarakat juga mempengaruhi perkembangan sosial remaja. Lingkungan masyarakat yang kondusif sangat dibutuhkan untuk mengendalikan maraknya kriminalitas dan hal-hal menyimpang yang dilakukan remaja. Selain itu, remaja juga harus memiliki kemauan untuk keluar atau menghindari terjadinya kenakalan remaja, dengan menyaring halhal yang mereka dapat.

\section{KESIMPULAN}

Remaja adalah masa peralihan dari anak-anak menuju dewasa. Umumnya masa ini disebut masa pencarian jati diri. Pada masa ini remaja sering kali melakukan kenakalan-kenakalan remaja. Salah satunya adalah keluar rumah di malam hari. Akibat yang ditimbulkan dapat merugikan remaja tersebut, keluarga, serta lingkungan sekitar. Peranan keluarga sangat penting dalam pengendalian tindakan remaja.

\section{DAFTAR PUSTAKA}

Sarwono, J. (2013). Mixed Methods Cara Menggabung Riset Kuantitatif dan Riset. Elex Media Komputindo.

Sumara, D. S., Humaedi, S., \& Santoso, M. B. (2017). Kenakalan remaja dan penanganannya. Prosiding Penelitian dan Pengabdian kepada Masyarakat, 4(2).

Aviyah, E., \& Farid, M. (2014). Religiusitas, kontrol diri dan kenakalan remaja. Persona: Jurnal Psikologi Indonesia, 3(02).

Surbakti, E. B. (2013). Kenakalan orang tua penyebab kenakalan remaja. Elex Media Komputindo.

Dako, R. T. (2012). Kenakalan remaja. Jurnal Inovasi, 9(02). 